Vol. 4: 463-472.

\title{
Relationship between bull dam herd characteristics and bias in estimated breeding value of bull
}

\author{
Pekka Uimari' and Esa A. Mäntysaari \\ Agricultural Research Centre of Finland, Institute of Animal Production, \\ FIN-31600 Jokioinen, Finland
}

\begin{abstract}
The objective of the study was to relate estimated breeding values (EBVs) of the parents' 305-days protein production and the bull dam herd-year characteristics to the empirical bias in pedigree indices (difference between the pedigree index and the final proof) of young bulls. Two animal model evaluations were carried out; one included records up to 1990 and the other up to spring 1992. The final data set included 242 bulls with pedigree indices, final proofs, parents' EBVs, production and herd information (the size, the average production and the intraherd standard deviation) of the dams. The average empirical bias in pedigree indices was $13.6 \mathrm{~kg}$. The correlation between the final proof of the bull and the EBVs of the bull sire or dam were 0.45 and 0.17 , respectively. The low correlation with bull dam EBV indicates the unreliability of the bull dam EBVs. Size of the herd and the standard deviation of production in the herd when bull dam produced its third lactation were correlated with the empirical bias in pedigree index. Pedigree indices of the bulls coming from small herds with high intraherd standard deviation were more biased than those from the big herds with low intraherd standard deviation. The best bulls, when grouped according to their final proofs, were sons of the highest EBV sires. EBVs of bull dams did not differ in the highest and the lowest final proof groups, but the dams of the best bull group had a higher first lactation record than the dams of the other bull groups.
\end{abstract}

Key words: animal model, dairy cattle evaluation, protein production

${ }^{\prime}$ Current address: Department of Animal Science, Montana State University, Bozeman, Montana 59717, USA

\section{Introduction}

In 1990, an animal model was adopted for dairy cattle evaluation in Finland. Economically the most important trait in the evaluation is 305-days protein yield. Some problems connected to evaluation of young bulls entering artificial insemination (AI) in Finland have been indicated by
Uimari and Mäntysaari (1993). The empirical accuracy $(r=0.37)$ of the young bull's pedigree index (the average of estimated breeding values (EBVs) of parents) calculated as a correlation between pedigree index and final proof (EBV of a bull when daughter information is available and the accuracy of the estimate approaches to 1) was less than what was expected from the amount of information available $(r=0.61)$. The reduction 


\section{AGRICULTURAL SCIENCE IN FINLAND}

\section{Uimari, P. \& Mäntysaari, E.A.: Bias in bull EBVs and herd characteristics of their dams}

was attributed to the selection of young bulls based on pedigree index. The other problem indicated was an empirical upward bias $(5 \mathrm{~kg})$ in pedigree indices calculated as a difference between pedigree index and final proof (Uimari and Mäntysaari 1993). This bias influenced bull's EBV when only a small number of daughters was available. Biased pedigree indices for production traits in animal model evaluation have also been reported by Ferris and Wiggans (1991), Mao et al. (1991) and Van Der Werf et al. (1994).

Bias in pedigree index is caused by errors in parents' EBVs. Because of the large number of offspring, EBV for bull sires can be considered quite reliable, if no systematic preferential treatments for daughters of bull sires exist. The more likely source of bias is the evaluation of bull dams. Biased cow EBV can be caused by heterogeneous intraherd variance (Brotherstone and Hill 1986, Vinson 1987). To address this problem, several statistical methods has been developed (Brotherstone and Hill 1986, Wiggans and Vanraden 1991, Gianola et al. 1992, San Cristobal et al. 1993). In Finnish evaluations the problem of heterogeneous variances has been addressed by Mäntysaari and Sillanpää (1993). With a crude precorrection of records by within herd standard deviation, they could reduce the bias in pedigree indices by $6 \%$. A higher reduction in bias (20\%) in Dutch evaluations was observed when within herd variances were standardized using a slightly different approach (Van Der Werf et al. 1994).

Another possible source of bias is preferential treatment of phenotypically superior cows. The degree of bias in bull dam evaluations depends on whether cow has received preferential treatment only in later lactations or in all lactations and also if the relatives have received preferential treatment (Kuhn et al. 1994). Largest potential sources of bias arise with preferential treatment of the cow and its multiple daughters made possible with embryo transfer (Kuhn et al. 1994). One way to handle this situation is to try to identify herds where preferential treatment is a possibility and reject these herds as sources of bull dams (Van Vleck 1986). The relationship between the intraherd variance and bias in the evaluation has been shown to be significant (Wilhelm and Mao 1989). Thus, preferential treatment and heterogeneous intraherd variance are not separate problems, because the reason for high intraherd variance could be genetic or environmental, i.e., different management for different animals.

The objectives of this study were 1) to determine the correlation between EBV of bull and EBVs of parents, 2) to relate the characteristics of the bull dam herd to the empirical bias in pedigree indices of young AI bulls and, 3) to determine the characteristics of the herds of genetically best bulls.

\section{Material and methods}

Two different estimated breeding values (EBV, and $\mathrm{EBV}_{2}$ ) of 305-days protein production for each animal were calculated. Evaluation 1 was based on a data set of production records up to 1990. Evaluation 2 was based on the information available in spring 1992 (official dairy evaluation in April 1992). For both evaluations, records were multiplicatively precorrected for the effects of calving season and lactation number by calving age. This was done to partially standardize the variances of records in different lactations and calving months. Precorrection factors were obtained from an earlier animal model run without precorrection. The evaluation model used was a single trait animal model with repeated measurements. Heritability used was 0.30 and repeatability between recods was 0.50 . The model and the technique to solve for EBVs was the same as in official national evaluation (Mäntysaari and Stranden 1991; Uimari and Mäntysaari 1993). No adjustment was applied for intraherd variances.

From these two evaluations, Ayrshire bulls born between 1984-1986 that had no daughters in the evaluation 1 but that had a repeatability over 0.9 in the evaluation 2 were chosen for closer 


\section{AGRICULTURAL SCIENCE IN FINLAND}

Vol. 4: 462-472.

inspection. In the following, these bulls will be called as young bulls and their EBVs from evaluations 1 and 2 will be referred as pedigree indeces and final proofs, respectively. For the young bulls the dams' herd characteristics and production information were examined. Herd characteristics studied were the number of cows in the comparison group, i.e., herd-year size, and average and standard deviation of 305-days protein production within herd-year. Bull dam production information included the first three 305days protein production records if available.

Correlations were calculated between the two different EBVs of young bulls (the pedigree index and the final proof), EBVs of dams and sires, and empirical bias in pedigree indices of young bulls (difference between the pedigree index and the final proof). Multiple regression techniques were used to determine if the empirical bias can be explained by different herd characteristics and dam records. The preliminary model included herd-year size, average herd-year production, intraherd standard deviation and production of dam. Similar model, with the pedigree index included as an independent variable, was used to predict the final proof of the young bull. The data were further divided into three groups of equal size based on the empirical bias or on the final proofs. The average bias, EBVs of young bull, sire and dam, production of dam and herd characteristics were computed for each group.

\section{Results}

Totally 242 young bulls did not have any daughters in the evaluation 1 and had repeatability over 0.9 in the evaluation 2 and were included in the further analysis. The average number of daughters in the evaluation 2 for these young bulls was 187. The EBVs of young bulls, EBVs of their sires and dams and the production and the herd characteristics of bull dams are given in Table 1. The empirical bias was $13.6 \mathrm{~kg}$ which is over two times larger than what were reported by Ui- mari and Mäntysaari (1993). The reasons for this change are the different heritabilities used in evaluations $(0.25$ and 0.30$)$ and different sets of bulls considered. The average EBVs of bull sires changed approximately $-2 \mathrm{~kg}$ from the evaluation 1 to the evaluation 2 . The reduction in bull dam evaluation was more substantial, falling from $23.1 \mathrm{~kg}$ down to $16.8 \mathrm{~kg}$, this being a result of the information from grand progeny. The difference between the first and the later lacta-

Table 1. Averages and standard deviations (SD) of 305-day protein production evaluations ${ }^{\mathrm{a}}$ (EBV) of 242 young bulls and their parents, production records and herd characteristics of bull dams.

\begin{tabular}{|c|c|c|}
\hline Variable & Mean & SD \\
\hline \multicolumn{3}{|l|}{ Young bull: } \\
\hline Pedigree index, $\mathrm{kg}$ & 23.94 & 8.94 \\
\hline Final proof, kg & 10.29 & 11.58 \\
\hline Empirical bias, kg & 13.64 & 10.84 \\
\hline \multicolumn{3}{|l|}{ Parents: } \\
\hline Sire $\mathrm{EBV}_{1}, \mathrm{~kg}$ & 25.31 & 14.94 \\
\hline Sire $\mathrm{EBV}_{2}, \mathrm{~kg}$ & 23.40 & 13.67 \\
\hline Dam EBV ${ }_{1}, \mathrm{~kg}$ & 23.14 & 10.11 \\
\hline Dam $\mathrm{EBV}_{2}, \mathrm{~kg}$ & 16.84 & 9.52 \\
\hline \multicolumn{3}{|l|}{ Production of bull dam: } \\
\hline $1^{\text {st }}$ lactation, $\mathrm{kg}$ & 265.73 & 31.34 \\
\hline $2^{\text {nd }}$ lactation, $\mathrm{kg}$ & 278.89 & 31.62 \\
\hline $3^{\text {rd }}$ lactation $^{\mathrm{b}}, \mathrm{kg}$ & 278.42 & 30.36 \\
\hline \multicolumn{3}{|l|}{ Bull dam's $1^{\text {st }}$ lactation: } \\
\hline Herd-year size & 11.20 & 10.46 \\
\hline Herd-year average, kg & 233.21 & 24.32 \\
\hline Herd-year $\mathrm{SD}^{\mathrm{c}}, \mathrm{kg}$ & 29.11 & 10.47 \\
\hline \multicolumn{3}{|l|}{ Bull dam's $2^{\text {nd }}$ lactation: } \\
\hline Herd-year size & 11.42 & 10.47 \\
\hline Herd-year average, kg & 239.94 & 26.36 \\
\hline Herd-year SD, kg & 30.96 & 10.66 \\
\hline \multicolumn{3}{|l|}{ Bull dam's $3^{\text {rd }}$ lactation ${ }^{\mathrm{b}}$ : } \\
\hline Herd-year size & 11.55 & 10.28 \\
\hline Herd-year average, kg & 243.77 & 24.37 \\
\hline Herd-year SD, kg & 30.60 & 11.00 \\
\hline
\end{tabular}


Uimari, P. \& Mäntysaari, E.A.: Bias in bull EBVs and herd characteristics of their dams

Table 2. Correlations between empirical bias, 305-day protein production evaluations ${ }^{\mathrm{a}}(\mathrm{EBV})$ of young bulls and their parents.

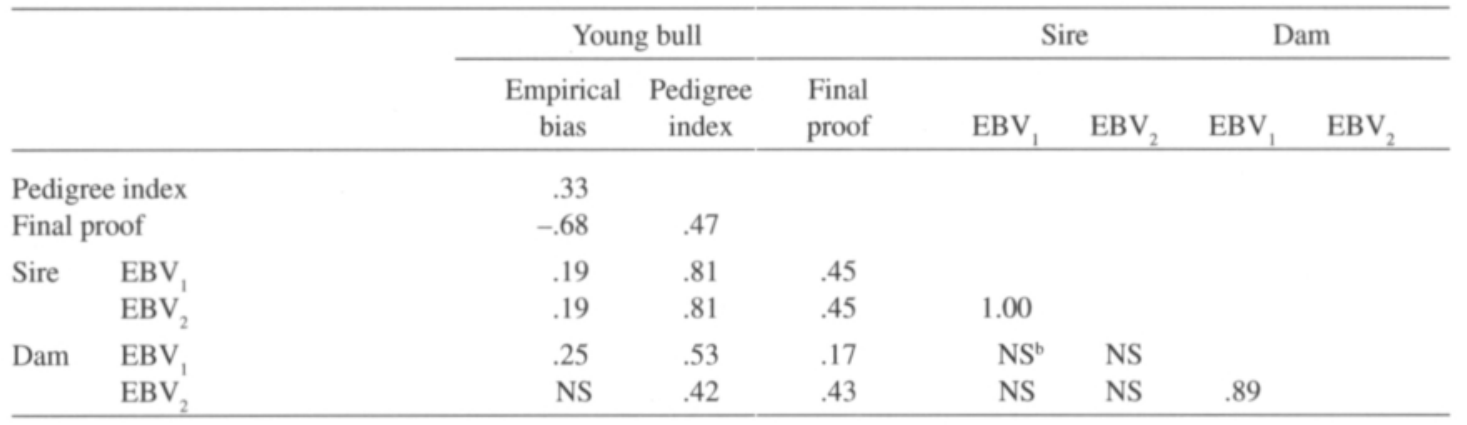

a Evaluation 1: data from 1978-1989 (Pedigree index and EBV $)$, evaluation 2: data from 1978-1992 (Final proof and $\mathrm{EBV}_{2}$ ).

${ }^{\mathrm{b}}$ Not significantly different from zero $(\mathrm{P}=0.05)$.

tion records of dams was relatively small caused by the precorrection of the records for calving season and for lactation number by calving age, as explained earlier. The average herd size and the intraherd standard deviation were fairly constant, but the average production of herd increased slightly over production years of bull dams.

Correlation between pedigree index and final proof was 0.47 (Table 2) giving the empirical repeatability of 0.22 , which is higher than what was reported in a previous study (Uimari and Mäntysaari 1993). Again, this is due to increased heritability and different set of bulls used in this study compared to a previous one. The correlation between sire EBVs was 1.00 indicating that the difference found in Table 1 between average EBVs of bull sires is constant across all bull sires. However, the correlation less than 1.00 between EBVs of bull dams indicates that the reduction in bull dam EBVs has not been constant for all bull dams. No correlation between EBVs of bull sire and bull dam was found. The correlation between pedigree index and the parent $E_{B V}$ s reflects the relative accuracy of the parents' EBVs giving more weight for sire information in pedigree index and thus higher correlation between pedigree index and sire $\mathrm{EBV}_{1}$ than pedigree index and dam $\mathrm{EBV}_{1}$. More interesting was the low correlation $(0.17)$ between bull's final proof and his dam's EBV, illustrating inaccurate evaluation of bull dams. The moderate positive correlation between sire EBVs and bias (0.19) implies that the sons of the sires with high EBV tended to have bigger bias than the sons of the sires with moderate or low EBV, thus some overestimation of the bull sire EBVs may exist. Also a moderate correlation existed between dam's EBV 1 and its son's empirical bias $(0.25)$, but no correlation was found between empirical bias and dam's $\mathrm{EBV}_{2}$.

Using the full multiple regression model (including the third year herd characteristics and the third production record of the bull dam) only the herd-year size and intraherd standard deviation were found to be significant in describing empirical bias (Table 3). Therefore another analysis was done using model which included population mean, herd-year size, and intraherd standard deviation only. The regression of empirical bias on intraherd standard deviation in the herdyear after third calving of the dam was 0.15 indicating a positive relationship between bias and intraherd standard deviation, for example, $10 \mathrm{~kg}$ difference between herd-year standard deviation corresponded to $1.5 \mathrm{~kg}$ bias. The negative regression coefficient for herd-year size $(-0.15)$ indicates that bulls coming from small herds tend to have more upward biased pedigree indices than bulls coming from big herds. When the first or 
Vol. 4: 462-472.

Table 3. Regression coefficients of different multiple regression models explaining the empirical bias and the final proof in 305-day protein production evaluations of young bulls.

\begin{tabular}{lcccc}
\hline Independent variable & \multicolumn{4}{c}{ Dependent variable } \\
\hline & \multicolumn{2}{c}{ Empirical bias } & \multicolumn{2}{c}{ Final proof } \\
\cline { 2 - 5 } Intercept & $6.94 \mathrm{NS}$ & $11.02^{* * *}$ & $-5.29 \mathrm{NS}$ & $-4.05 \mathrm{NS}$ \\
Pedigree index & & & $0.65^{* * *}$ & $0.66^{* * *}$ \\
$3^{\text {rd lactation: }}$ & & & & \\
Production of dam & $0.00 \mathrm{NS}$ & & $0.03 \mathrm{NS}$ & \\
Herd-year size & $-0.15^{*}$ & $-0.16^{*}$ & $0.13^{*}$ & $0.14^{*}$ \\
Herd-year average & $0.02 \mathrm{NS}$ & & $-0.03 \mathrm{NS}$ & \\
Herd-year SD & $0.15^{*}$ & $0.15^{*}$ & $-0.15^{*}$ & $-0.11^{*}$ \\
\hline
\end{tabular}

Significance levels: ${ }^{* * *} \mathrm{P}=0.001,{ }^{* *} \mathrm{P}=0.01,{ }^{*} \mathrm{P}=0.05,{ }^{+} \mathrm{P}=0.1, \mathrm{NS}$ the variable is not significantly different from 0 .

a Standard deviation of protein production within herd-year.

the second herd-year size and intraherd standard deviation were used as independent variables both came up to be nonsignificant. Overall, the coefficients of determination for the models were very low. For the best fitting model the coefficient was only 0.06 , thus even the best model was rather poor in explaining the variation in empirical bias.

Using the final proof as a dependent variable the bulls coming from the large herds with small herd-year standard deviation maintained their pedigree index better than bulls coming from small herds with large intraherd standard deviation.

When bulls were classified according to the empirical bias in pedigree index, both the average of final proofs and the average of pedigree indices varied significantly among the groups (Table 4). However, based on the averages of pedigree indices in each category, the expectations of the bulls in high bias category had been much higher than in the medium or the low bias categories. These expectations have been caused mainly by outstanding bull dam EBVs, although the mean EBV of bull sires has been higher in high bias group than in others. Bulls in the high bias group had dams with higher $3^{\text {rd }}$ production than bulls in the medium and the low groups. The only herd characteristics which varied according to empirical bias was intraherd stand- ard deviation when bull dam produced its $3^{\text {rd }}$ lactation record.

Young bulls with the highest final proofs were the progeny of the top matings, as was expected (Table 5). A significant difference $(14.5 \mathrm{~kg})$ was found between EBVs of the sires of the highest and the lowest bulls. Conversely, the difference between the averages of dam's $\mathrm{EBV}_{1}$ in the highest and the lowest ranking bull groups was not significant, but the difference in the first lactation records between the best and the other bull groups was significant. However, no significant difference in the first lactation record was found between the low and the medium bull groups. No other significant differences were found between herd characteristics of the three bull groups.

\section{Discussion}

The regression of recent on early EBVs provide a simple test to detect either inappropriate variance components used in evaluation or bias associated with EBVs (Reverter et al. 1994). The regression coefficient calculated from our data set for 242 young bulls was 0.65 , which was sig- 
Uimari, P. \& Mäntysaari, E.A.: Bias in bull EBVs and herd characteristics of their dams

Table 4. Averages of 305-day protein production evaluations ${ }^{\mathrm{a}}$ (EBV) and herd characteristics of bull dams for young bulls divided into three equal size groups according to empirical bias (standard errors in parentheses).

\begin{tabular}{|c|c|c|c|c|}
\hline & Low & Medium & High & \\
\hline Variable & $-17-9 \mathrm{~kg}$ & $9-19 \mathrm{~kg}$ & $19-41 \mathrm{~kg}$ & \\
\hline \multicolumn{5}{|l|}{ Young bull: } \\
\hline Pedigree index, kg & $21.32(0.95)$ & $23.44(0.97)$ & $27.11(0.96)$ & *** \\
\hline Final proof, kg & $19.46(0.99)$ & $9.70(1.00)$ & $1.63(1.03)$ & *** \\
\hline Empirical bias, $\mathrm{kg}$ & $1.86(0.58)$ & $13.74(0.33)$ & $25.47(0.69)$ & *** \\
\hline \multicolumn{5}{|l|}{ Parents: } \\
\hline Sire EBV, kg & $22.87(1.61)$ & $25.72(1.71)$ & $27.38(1.65)$ & NS \\
\hline Sire $\mathrm{EBV}_{2}, \mathrm{~kg}$ & $21.21(1.47)$ & $23.85(1.56)$ & $25.18(1.52)$ & NS \\
\hline $\mathrm{Dam} \mathrm{EBV}_{1}, \mathrm{~kg}$ & $20.69(0.99)$ & $21.51(0.96)$ & $27.26(1.27)$ & *** \\
\hline Dam EBV ${ }_{2}, \mathrm{~kg}$ & $18.31(1.02)$ & $15.56(0.97)$ & $16.68(1.18)$ & NS \\
\hline \multicolumn{5}{|l|}{ Production of bull dam: } \\
\hline $1^{\text {st lactation, } \mathrm{kg}}$ & $266.36(3.74)$ & $258.93(3.21)$ & $271.99(3.41)$ & NS \\
\hline $2^{\text {nd }}$ lactation, kg & $277.31(3.20)$ & $273.49(2.79)$ & $285.94(4.33)$ & NS \\
\hline $3^{\text {rd }}$ lactation, kg & $275.59(3.08)$ & $273.77(2.92)$ & $285.99(4.12)$ & $*$ \\
\hline \multicolumn{5}{|l|}{ Bull dam's $1^{\text {st lactation: }}$} \\
\hline Herd-year size & $12.14(1.34)$ & $12.16(1.36)$ & $9.30(0.63)$ & NS \\
\hline Herd-year average, kg & $237.04(2.87)$ & $226.44(2.21)$ & $236.23(2.89)$ & NS \\
\hline Herd-year $\mathrm{SD}^{b}, \mathrm{~kg}$ & $28.63(10.99)$ & $28.55(1.12)$ & $30.17(1.37)$ & NS \\
\hline \multicolumn{5}{|l|}{ Bull dam's $2^{\text {nd }}$ lactation: } \\
\hline Herd-year size & $12.41(1.36)$ & $12.34(1.33)$ & $9.48(0.65)$ & NS \\
\hline Herd-year average, kg & 242.78 (2.79) & $233.40(2.35)$ & $243.72(3.48)$ & NS \\
\hline Herd-year SD, kg & $30.01(1.12)$ & $30.15(0.99)$ & $32.66(1.41)$ & NS \\
\hline \multicolumn{5}{|l|}{ Bull dam's $3^{\text {rd }}$ lactation: } \\
\hline Herd-year size & $12.66(1.36)$ & $12.29(1.36)$ & $9.69(0.62)$ & NS \\
\hline Herd-year average, $\mathrm{kg}$ & 245.70 (2.79) & $238.01(2.13)$ & $247.76(3.23)$ & NS \\
\hline Herd-year SD, kg & $28.29(1.14)$ & $29.41(0.93)$ & $34.10(1.53)$ & *** \\
\hline
\end{tabular}

Significance levels of the difference between Low and High groups: *** $\mathrm{P}<0.001,{ }^{* *} \mathrm{P}<0.01,{ }^{*} \mathrm{P}<0.05$, NS the difference is not significant.

a Evaluation 1: data from 1978-1989 (Pedigree index and EBV $)_{1}$, evaluation 2: data from 1978-1992 (Final proof and $\mathrm{EBV}_{2}$ ).

${ }^{b}$ Standard deviation of protein production within herd-year.

nificantly $(\mathrm{P}=0.001)$ different from the expected value of 1 (Reverter et al. 1994). The other simple method suggested by Reverter et al. (1994) is the correlation between subsequent EBVs, which has an expected value equal to the square root of the ratio of the mean repeatabilities of the evaluations. The correlation between pedigree index and final proof for the 242 young bulls was 0.47 which is significantly different from the expected value of the 0.65 . These two simple statistics indicate that the $13.6 \mathrm{~kg}$ empirical bias in pedigree indices was significant.
High correlation $(0.45)$ was found between $\mathrm{EBV}_{1}$ of the bull sire and final proof of his son. On the contrary, weak correlation $(0.17)$ was found between $E B V_{1}$ of bull dam and final proof of its son. The conclusion from these correlations is that EBV of a bull dam is a fairly poor indicator of its son's final proof and that the selection of bull sires is crucial for genetic progress. On the other hand, no better criteria for bull dam selection than EBVs, even if biased, are available, so breeders must rely on those.

The only significant effects found in predict- 
Vol. 4: 462-472.

Table 5. Averages of 305-day protein production evaluations (EBV) and herd characteristics of bull dams for young bulls divided into three equal size groups according to final proofs (standard errors in parentheses).

\begin{tabular}{|c|c|c|c|c|}
\hline & Low & Medium & High & \\
\hline Variable & $-20-5 \mathrm{~kg}$ & $5-15 \mathrm{~kg}$ & $15-40 \mathrm{~kg}$ & \\
\hline \multicolumn{5}{|l|}{ Young bull: } \\
\hline Pedigree index, $\mathrm{kg}$ & $20.38(0.88)$ & $22.66(0.98)$ & $28.84(0.88)$ & *** \\
\hline Final proof, kg & $-2.26(0.63)$ & $10.14(0.33)$ & $23.18(0.69)$ & *** \\
\hline Empirical bias, kg & $22.65(0.92)$ & $12.52(0.95)$ & $5.66(0.90)$ & $* * *$ \\
\hline \multicolumn{5}{|l|}{ Parents: } \\
\hline Sire $\mathrm{EBV}_{1}, \mathrm{~kg}$ & $17.87(1.46)$ & $25.80(1.55)$ & $32.35(1.59)$ & $* * *$ \\
\hline Sire $\mathrm{EBV}_{2}, \mathrm{~kg}$ & $16.57(1.33)$ & $23.85(1.42)$ & $29.87(1.45)$ & $* * *$ \\
\hline Dam EBV $_{1}, \mathrm{~kg}$ & $23.27(1.20)$ & $20.42(1.02)$ & $25.74(1.09)$ & NS \\
\hline $\operatorname{Dam~EBV}_{2}, \mathrm{~kg}$ & $14.01(1.06)$ & $14.48(0.89)$ & $22.07(0.99)$ & *** \\
\hline \multicolumn{5}{|l|}{ Production of bull dam: } \\
\hline $1^{\text {th lactation, } \mathrm{kg}}$ & $264.75(3.36)$ & $258.08(3.24)$ & $274.38(3.68)$ & $*$ \\
\hline $2^{\text {nd }}$ lactation, $\mathrm{kg}$ & $278.00(3.55)$ & $273.45(3.26)$ & $285.24(3.68)$ & NS \\
\hline $3^{\text {rd }}$ lactation, kg & $278.04(3.31)$ & $273.42(2.93)$ & $283.75(3.97)$ & NS \\
\hline \multicolumn{5}{|l|}{ Bull dam's 1" lactation: } \\
\hline Herd-year size & $9.41(0.55)$ & $12.20(1.38)$ & $12.01(1.37)$ & NS \\
\hline Herd-year average, kg & $231.96(2.69)$ & $230.06(2.57)$ & $237.62(2.82)$ & NS \\
\hline Herd-year $\mathrm{SD}^{b}, \mathrm{~kg}$ & $29.43(1.30)$ & $27.98(1.03)$ & $29.93(1.16)$ & NS \\
\hline \multicolumn{5}{|l|}{ Bull dam's $2^{\text {nd }}$ lactation: } \\
\hline Herd-year size & $9.71(0.59)$ & $12.56(1.37)$ & $11.99(1.37)$ & NS \\
\hline Herd-year average, kg & $239.20(3.13)$ & $237.46(2.53)$ & $243.17(3.12)$ & NS \\
\hline Herd-year SD, kg & $31.81(1.16)$ & $29.64(1.15)$ & $31.40(1.26)$ & NS \\
\hline \multicolumn{5}{|l|}{ Bull dam's $3^{\text {rd }}$ lactation: } \\
\hline Herd-year size & $10.16(0.58)$ & 11.89 & $12.62(1.43)$ & NS \\
\hline Herd-year average, $\mathrm{kg}$ & $243.64(2.65)$ & $241.42(2.61)$ & $246.22(3.04)$ & NS \\
\hline Herd-year SD, kg & $32.40(1.17)$ & $29.33(1.18)$ & $30.01(1.38)$ & NS \\
\hline
\end{tabular}

Significance levels of the difference between Low and High groups: *** $\mathrm{P}<0.001,{ }^{* *} \mathrm{P}<0.01,{ }^{*} \mathrm{P}<0.05$, NS the difference is not significant.

" Evaluation 1: data from 1978-1989 (Pedigree index and EBV,), evaluation 2: data from 1978-1992 (Final proof and $\mathrm{EBV}_{2}$ ).

${ }^{b}$ Standard deviation of protein production within herd-year.

ing the empirical bias using the multiple regression technique were the herd-year size and the intraherd standard deviation at the third lactation of the bull dam. The birth year of the young bull was not related to the lactation history of the dam, as was done by Wilhelm and Mao (1989). In our data set, the bull dams were selected after four lactations, on average, before the son was bought for AI-use. Only $22 \%$ of the bull calves were born at second or third calving of their dams. However, we believe that the moment when the bull calf is sold to be unimpor- tant compared to the moment when the cow is promoted to be a bull dam.

When bulls were grouped according their final proofs, the average EBV of the sires of the highest group bulls differed significantly from the average EBV of the sires of the lowest group bulls. On the contrary, no significant difference was found between average EBV of bull dams of different bull groups. This provide an indicator of the difficulty in distinguishing the very best bull dams from all selected bull dams. It may be beneficial to select bull dams based on their 


\section{AGRICULTURAL SCIENCE IN FINLAND}

Uimari, P. \& Mäntysaari, E.A.: Bias in bull EBVs and herd characteristics of their dams

first lactation records. This can be supported by the significant variation in the first lactation records of bull dams between different final proof groups found in this study as well as other evidences which have shown that the EBVs based on the first lactation records are more reliable predictors of the bull dams' true genetic values than EBVs based on all lactation records (Rothschild et al. 1981, Pedersen 1991, Mäntysaari and Sillanpää 1993). Early selection can also be more efficient than selection based on all lactation records even when bias occur (Weigel et al. 1994). However, when biases occur in all lactations including the first lactation or within cow families, selection based on first lactation EBVs is less efficient than selection on EBVs based on all lactation records (Weigel et al. 1994). Other herd characteristics did not vary significantly according to final proof, so although the bulls coming from small herds with high intraherd standard deviation more likely have upward biased EBVs than other bulls, this does not mean that the final proof of those bulls will necessarily be lower than other bulls.

Mäntysaari and Sillanpää (1993) tested several models describing the management effect and found that the most effective way to reduce bias is to separate first lactations from the later lactations into different herd-years. Such definition lead to significantly smaller bias in pedigree indices of young bulls. They suggested that an interaction between lactation number and herd yields presumably causes larger differences in different lactations in herds with high produc- tion. This phenomenon might explain why in Tables 4 and 5 the first lactation production of bull dams does not reach the same level as the second and the third lactation protein production although the records were multiplicatively precorrected before running the evaluation. Multiplicative correction factors for lactation number effect, however, did not completely correct the interaction and thus a division of herdyear effects by lactation number seemed advisable, as has been adapted in Finnish dairy cattle evaluations since fall 1993.

\section{Conclusions}

According the results the AI co-operatives should select the young bulls from the matings of the animals having the highest estimated breeding values. The use of the outstanding bulls as bull sires is the most important factor in genetic progress as long as the evaluation of bull dams is less reliable. Because the herd size and the intraherd standard deviation at bull dam's third lactation appeared to be related to biased pedigree indices of young bulls, AI co-operatives would be well advised to take a more critical view on pedigree indices of young bulls coming from small herds with high within herd standard deviation. Finally, possibility for selection of bull dams based purely on first lactation records should be studied.

\section{References}

Brotherstone, S. \& Hill, W.G. 1986. Heterogeneity of variance amongst herds for milk production. Animal Production 42: 297-303.

Ferris, T.A. \& Wiggans, G.R. 1991. Accuracy of animal model parent evaluations in predicting daughter yield deviations for Al sampled bulls. Journal of Dairy Science 74, Supplement: 265 / Abstract.

Gianola, D., Foulley, J.L., Fernando, R.L., Henderson,
C.R. \& Weigel, K.A. 1992. Estimation of heterogeneous variances using empirical Bayes methods: theoretical considerations. Journal of Dairy Science 75: 2805-2823. Kuhn, M.T., Boettcher, P.J. \& Freeman, A.E. 1994. Potential biases in predicted transmitting abilities of females from preferential treatment. Journal of Dairy Science 77: 2428-2437.

Mao, I.L., Dong, M.C. \& Meadows, C.E. 1991. Selec- 
Vol. 4: 462-472.

tion of bulls for progeny testing using pedigree indices and characteristics of potential bull-dams' herds. Journal of Dairy Science 74: 2747-2756.

Mäntysaari, E.A. \& Sillanpää, M. 1993. Bias in pedigree indices of dairy bulls: Should the management group effects be fixed and should we use smaller heritability? 44th Annual Meeting of the European Association for Animal Production, Aarhus, Denmark. Vol 1:236-237. Abstract.

- \& Stranden, I. 1991. Animal model evaluation for production and reproduction traits in Finnish dairy cattle. 42nd Annual Meeting of the European Association for Animal Production, Aarhus, Denmark. Vol 1: 96-97. Abstract.

Pedersen, G.A. 1991. Realized efficiency of bull dam selection in dairy cattle breeds. 42nd Annual Meeting of the European Association for Animal Production, Aarhus, Denmark. Vol 1: 142-143. Abstract.

Reverter, A., Golden, B.L., Bourdon, R.M. \& Brinks, J.S., 1994. Technical note: Detection of bias in genetic predictions. Journal of Animal Science 72: 34-37.

Rothschild, M.F., Douglass, L.W. \& Powell, R.L. 1981. Prediction of son's modified contemporary comparison from pedigree information. Journal of Dairy Science 64: 331-341.

San Cristobal, M., Foulley, J.L. \& Manfredi, E. 1993. Inference about multiplicative heteroscedastic components of variance in a mixed linear Gaussian model with an application to beef cattle breeding. Genetic Selec- tion Evolution 25: 3-10.

Uimari, P. \& Mäntysaari, E.A. 1993. Repeatability and bias of estimated breeding values for dairy bulls and bull dams calculated from animal model evaluations. Animal Production 57: 175-182.

Vinson, W.E. 1987. Potential bias in genetic evaluations from differences in variation within herds. Journal of Dairy Science 70: 2450-2455.

Vleck, L.D. van. 1986. Evaluation of dairy cattle breeding programs: specialized milk production. Proceedings of the 3rd World Congress on Genetic Applied to Livestock Production, Lincoln, NE 9: 141.

Weigel, D.J., Pearson, R.E. \& Hoeschele, I. 1994. Impact of different strategies and amounts of preferential treatment on various methods of bull-dam selection. Journal of Dairy Science 77: 3163-3173.

Werf, J.H.J. van der, Meuwissen, T.H.E. \& De Jong, G. 1994. Effect of correction for heterogeneity of variance on bias and accuracy of breeding value estimation for Dutch dairy cattle. Journal of Dairy Science 77: 31743184.

Wiggans, G.R. \& VanRaden, P.M. 1991. Method and effect of adjustment for heterogeneous variance. Journal of Dairy Science 74: 4350-4357.

Wilhelm, A.E. \& Mao, I.L. 1989. Relationship between characteristics of herd of bull-dams and predicting transmitting ability of young bulls. Journal of Dairy Science 72: 2395-2401. 
Uimari, P. \& Mäntysaari, E.A.: Bias in bull EBVs and herd characteristics of their dams

\section{SELOSTUS}

\section{Sonnin jalostusarvon ennusteen ja sonnin emän karjan tunnuslukujen välinen yhteys \\ Pekka Uimari ja Esa Mäntysaari \\ Maatalouden tutkimuskeskus}

Artikkelin tavoitteena oli tutkia onko vanhempien jalostusarvojen ennusteilla ja sonnin emän karjan eri tunnusluvuilla yhteyttä keinosiemennykseen valittujen nuorsonnien odotusarvojen harhaisuuteen.

Tutkimuksessa tehtiin kaksi eläinmalliarvostelua; toinen arvostelu perustui vuoteen 1990 ja toinen kevääseen 1992 mennessä kerättyihin 305-päivän valkuaistuotoksiin. Näistä arvosteluista koottiin 242 sonnin otosaineisto, joka sisälsi sonnien odotusarvot, jälkeläisarvostelutulokset ja vanhempien jalostusarvojen ennusteet. Sonnin emien tuotostiedot sekä sonnin emän karjon koko, keskituotos ja tuotosten hajonta olivat myös käytössä.

Odotusarvojen keskimääräinen harha oli 13,6 kg. Korrelaatio sonnin jälkeläisarvostelutuloksen ja sonnin isän jalostusarvon ennusteen välillä oli 0,45 , mutta vastaava korrelaation sonnin emän kanssa oli vain 0,17 osoittaen sonnin emien jalostusarvojen ennus- teiden epäluotettavuutta. Sonnin emän karjan koko ja tuotosten keskihajonta, kun sonnin emä tuotti kolmannen lypsytuotoksen, olivat yhteydessä odotusarvon harhaisuuteen. Mitä pienempi karja ja mitä suurempi tuotosten hajonta karjassa oli sitä harhaisempia odotusarvot olivat. Kun sonnit luokiteltiin jälkeläis-arvostelutuloksen perusteella, parhaat nuoret sonnit olivat parhaiden isäsonnien poikia. Sonniryhmät eivät eronneet emän jalostusarvon ennusteen perusteella, mutta parhaiden sonnien emien ensimmäinen tuotos oli korkeampi kuin muiden ryhmien sonnien.

Edellisten tulosten perusteella keinosiemennysosuuskuntia kehoitetaan valitsemaan nuorsonnit odotusarvon perusteella, mutta samalla huomioimaan odotusarvon mahdollinen harhaisuus etenkin, jos sonni tulee pienestä karjasta, jossa on suuri tuotosten hajonta. 